\title{
The Relationship between House Prices and Stock Prices in Saudi Arabia: An Empirical Analysis
}

\author{
Khaled I. Batayneh ${ }^{1} \&$ Abdullah M. Al-Malki ${ }^{1}$ \\ ${ }^{1}$ Administrative Sciences Department, King Saud University, Riyadh, Saudi Arabia \\ Correspondence: Khaled I. Batayneh, Administrative Sciences Department, King Saud University, Riyadh, Saudi \\ Arabia. E-mail: kbatayneh@ksu.edu.sa
}

Received: November 10, 2014

Accepted: November 26, 2014

Online Published: January 25, 2015

doi:10.5539/ijef.v7n2p156

URL: http://dx.doi.org/10.5539/ijef.v7n2p156

\begin{abstract}
This paper investigates empirically the relationship between stock market prices and house prices in Saudi Arabia. Using yearly data for the period from 1985 to 2012 we conducted a Granger-causality test, Impulse response functions and Variance decompositions that were simulated from the estimated unrestricted vector autoregressive (VAR). Results suggest that stock market and economic growth play a major role in determining house prices. Granger causality results show that stock market prices and the economic growth have a causal impact on house prices. Impulse response functions indicate there is a negative relationship between stock market prices and house prices and also there is a positive relationship between economic growth and house prices. Variance decompositions show that the stock market prices is the most important variable that explains the variation of house prices, followed by economic growth.
\end{abstract}

Keywords: house prices, impulse response functions, Saudi Arabia, stock market prices, variance decomposition

\section{Introduction}

It is recognized that macroeconomic and financial variables have an impact on housing prices in many countries around the world. For example, the global financial and economic recession of 2008 was caused by the collapse of U.S. mortgage market. In recent years, Saudi Arabia has experienced hiking real estate prices and stock market prices fluctuations. Therefore, investigating the relationship between real estate and stock prices in order to promote stable and sustainable development of the economy becomes a necessity.

The correlation between stock prices and house prices has been discussed in the literature. Two mechanisms have been introduced to interpret this correlation. The first one is known as 'wealth effect' which assumes that houses are investment and consumption goods. Therefore, as a result of the rise in the value of stock portfolio due to escalating stock prices, investors will feel more comfortable about their wealth which may motivate them to increase their demand for housing and shift the demand curve upward, causing real estate prices to rise.

The second one is the credit-price effect. According to this theory, firms are credit-constrained and real estate serves as collateral for loans. The credit-price effect theory suggests that the increase in house prices (higher collateral values for loans) would make it cheaper to firms and individuals to get more loans at lower cost. As a result, firms would expand their investments, which in turn lead the stock prices to rise (Kapopoulous \& Siokis, 2005).

Moreover, there is recognition for the importance of the interactive nexus between housing markets and the financial variables. That is why the relation between house prices and financial market has important policy implications.

Most of empirical studies on the relationship between house prices and stock prices were conducted in the context of developed countries and more advanced Asian countries. Few studies investigated this relation in developing countries and none in Saudi Arabia.

This study contributes to the current literature by shedding light on the relationship between housing market and financial market in Saudi Arabia. To the best of our knowledge, this study is the first to apply vector Autoregression (VAR) to explain the relationship between housing market and the stock market in Saudi Arabia.

The objective of this study is to analyze empirically the existence of relation between housing prices and stock 
prices in Saudi Arabia. In other words, the aim of this study is to find out the relation between the housing market and financial market in Saudi Arabia by using yearly data from 1985-2012. This paper is organized as follows: Section 1 is the introduction. Section 2 presents literature review. Section 3 provides Empirical Framework. Empirical Results are discussed in section 4. Section 5 reports conclusions.

\section{Literature Review}

The relationship between stock prices and house prices has got a lot of attention in both the academic and practitioner literatures. Economists and interested researchers have been discussing this relation from several aspects and using different methods of analyses, whether in developed countries or the more advanced Asian countries.

Studies focused on the U.S. and U.K to find out the correlation between real estate prices and stock prices viewing both as assets return (Ibbotson \& Siegel, 1984; Hartzell, 1986; Worzala \& Vandell, 1993; Gyourko \& Keim, 1992; Eichholtz \& Hartzell, 1996). They found a negative correlation between housing and stock returns However, Gyourko and Keim (1992), found a positive correlation between the two assets. Hoesli and Hamelink (1997), who studied this issue in Switzerland and Lizieri and Satchell (1997) who focused on the UK, also found a correlation between housing and stock returns. An empirical study by Quan and Titman (1999) used data form 17 countries to examine the relation between stock returns and changes in property values and rents. The study found that, with the expectation of Japan, the contemporaneous relationship between real estate prices and stock returns was not statistically significant. They also found that real estate prices to be significantly influenced by GDP growth rate. Bonnie (1998) developed a VAR model to analyze the impact of macroeconomic aggregate on housing prices and stock of houses on national and regional levels for U.S. The results confirmed that the interaction between housing market and economic variables existed. Sing and Tan (2013) tried to test the time-varying correlations of returns between general stocks and direct real estate. They used (GARCH) model and included data for U.S.A, UK, Ireland, Australia, Hong Kong and Singapore. They found significant time-varying effects in conditional covariance between stock return and direct real estate return. Kakes and Van den End (2004) tried to find out if stock prices affect house prices in Netherland. Their results support the idea that equity is a determinant of house prices. Kapopoulos and Soiokis (2005) attempted to clarify the relationship between real estate prices and stock prices in Greece by using Granger Causality. Their results indicated that stock prices Granger cause real estate prices, which is in favor of the wealth effect hypothesis. Their findings were for Athens real estate prices not for other urban real estate prices. Sim and Chang (2006) examined the relationship between stock and real estate prices in Korea using vector autoregression (VAR). They found significant evidence from Granger causality test and impulse response functions that house and land prices influence stock prices. Ibrahim, Padli, and Baharom (2009) used the autoregressive distributive lags (ARDL) cointegration test to examine the long-run relationship between housing prices, real GDP, consumer price index and stock prices in Thailand. Their findings indicated positive relationship between housing prices and the macroeconomic and financial variables chosen. Another study for Ibrahim (2010) found a unidirectional causality that runs from stock prices to house prices in Thailand. The results support the wealth effect theory. The results were based on Granger causality tests, impulse response functions and variance decompositions. Hui and $\mathrm{Ng}$ (2012) used Granger causality test, variance decomposition and CUSUM test to examine the short and long-run interrelationship between Hong Kong's property prices and stock indexes. They found that the correlation between the two variables had become weaker over time. Few studies have examined the long-run relation between house prices and stock prices. Takala and Pere (1991) examined the long-run relationship between the house prices and stock prices in Finland. Their results show that the long-run relationship between the two prices exists and that there is Granger causality which runs from stock prices to the house prices, which support wealth effect theory. In the same context Oikarinen (2010) findings support long relationship between house price and stock prices.

\section{The Empirical Framework}

\subsection{The Data}

The variables used in the VAR standard VAR model are: housing price index (HPI), stock price index (SPI) and real income or real gross domestic product (RGDP). Real income or real gross domestic product (RGDP) was included in the model due to the important role of real income in influencing housing demand and supply. All variables are converted to natural logarithms. Real GDP and stock price index (SPI) were obtained from Saudi Arabian Monetary Agency (SAMA), and housing price index (HPI) was obtained from Central Department of Statistic and Information. The three variables are depicted in Figure 1 and descriptive statistics for the variables are provided in Table 1. 

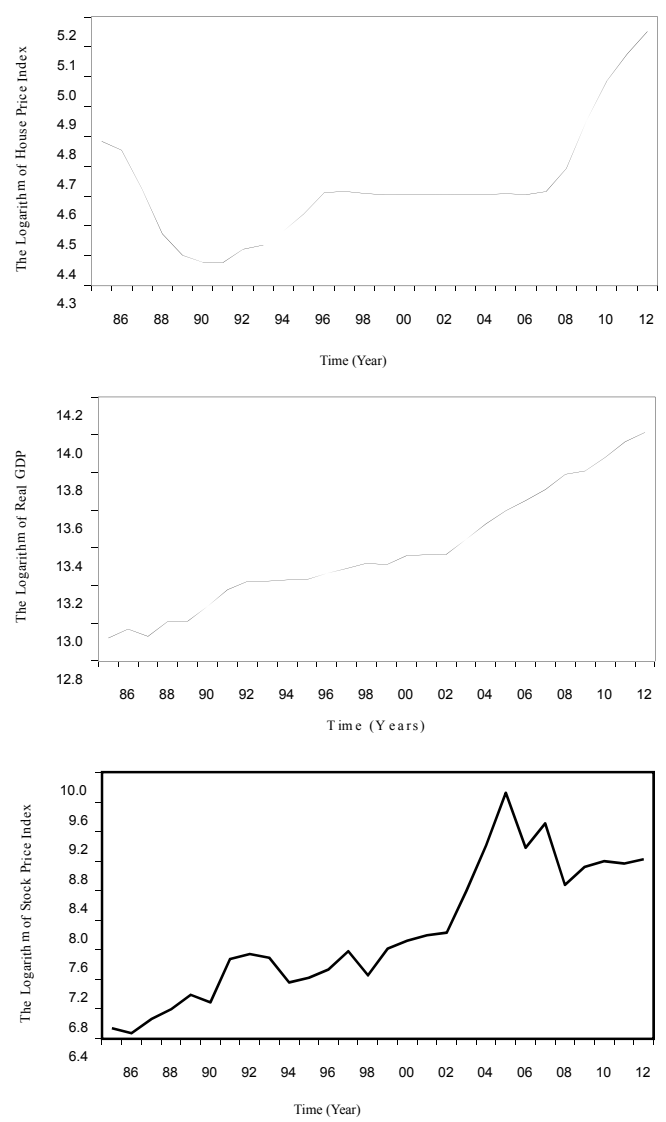

Figure 1. Plot of the sample series, 1985-2012

Table 1. Summary statistics of natural logarithm of House Price Index (HPI), Natural Logarithm of Real (GDP), and natural logarithm of Stock Price Index (SPI), 1985-2012

\begin{tabular}{llcc}
\hline Variable Descriptive & LHPI & LRGDP & LSPI \\
\hline Mean & 4.633270 & 13.38102 & 7.834634 \\
Median & 4.605670 & 13.31441 & 7.597322 \\
Maximum & 5.151797 & 14.01267 & 9.723921 \\
Minimum & 4.377014 & 12.92141 & 6.470846 \\
Std. Dev. & 0.193631 & 0.316485 & 0.907333 \\
Skewness & 1.119821 & 0.448822 & 0.352130 \\
Kurtosis & 3.984598 & 2.225781 & 2.029961 \\
Jarque-Bera & 6.982999 & 1.639378 & 1.676450 \\
Probability & 0.030455 & 0.440569 & 0.432477 \\
\hline
\end{tabular}

\subsection{Methodology}

Time series econometric techniques are used to test the relationship between stock prices and house prices. Depending on the cointegration test results between the three variables included in the system we can choose one of two conventional econometric techniques: the Unrestricted Vector Autoregression (UVAR) specification or an Error Correction Model (ECM) specification. The UVAR model can be used in a situation of the absence of cointegration - long-run relationship - among the variables used in analysis. Therefore, the UVAR model can be written as a linear function as following:

$$
\begin{gathered}
H P I_{t=} \alpha_{0}+\mu_{1} H P I_{t-1}+\ldots \mu_{P} H P I_{t-P}+\beta_{1} R G D P_{t-1}+\ldots+\beta_{p} R G D P_{t-p}+\delta_{1} S P I_{t-1}+\ldots+\delta_{p} S P I_{t-p}+u_{1 t} \\
S P I_{t=} \gamma_{0}+\varphi_{1} S P I_{t-1}+\ldots \varphi_{P} S P I_{t-P}+\rho_{1} R G D P_{t-1}+\ldots+\rho_{p} R G D P_{t-p}+\sigma_{1} H P I_{t-1}+\ldots+\sigma_{p} H P I_{t-p}+u_{2 t}
\end{gathered}
$$

where, HPI is house prices, RGDP is real gross domestic product and SPI is stock prices. Also, $\alpha_{0}$ and $\gamma_{0}$ are constants, $\mu_{i}, \beta_{i}, \delta_{i}, \varphi_{i}, \rho_{i}$, and $\sigma_{i}$ are matrices of lag coefficients are up to some lag length $\mathrm{P}$, and $\mathrm{u}_{1 \mathrm{t}}$ and $\mathrm{u}_{2 \mathrm{t}}$ are 
vectors of error terms.

In case of finding cointegration among the variables, an error correction model will be used for further analysis. The error correction model may be written as the following:

$$
\begin{aligned}
& \Delta H P I_{t=} \alpha_{0}+\lambda u_{t-1}+\mu_{1} \Delta H P I_{t-1}+\ldots \mu_{P} \Delta H P I_{t-P}+\beta_{1} \Delta R G D P_{t-1}+\ldots+\beta_{p} \Delta R G D P_{t-p}+\delta_{1} \Delta S P I_{t-1}+\ldots+\delta_{p} \Delta S P I_{t-p}+\varepsilon_{l t} \\
& \Delta S P I_{t=} \gamma_{0}+\theta u_{t-1}+\varphi_{1} \Delta S P I_{t-1}+\ldots \varphi_{P} \Delta S P I_{t-P}+\rho_{1} \Delta R G D P_{t-1}+\ldots+\rho_{p} \Delta R G D P_{t-p}+\sigma_{1} \Delta H P I_{t-1}+\ldots+\sigma_{p} \Delta H P I_{t-p}+\varepsilon_{2 t}
\end{aligned}
$$

where, $\Delta$ is the first difference operator, $\mathrm{u}_{\mathrm{t}-1}$ is the error correction term and measuring the deviations of HPI or SPI from their long run values, and $\varepsilon_{1 t}, \varepsilon_{2 t} \sim$ I.I.D $\left(0, \sigma^{2}\right)$.

The next step is to find VAR Causality test, derive impulse response functions and finally present the variance decomposition.

In general the Granger (1969) approach used to test whether $x$ causes $y$ by finding how much of the current $y$ can be explained by past values of $y$ and then to see whether adding lagged values of $\mathrm{x}$ can improve the explanation. $\mathrm{y}$ is said to be Granger-caused by $\mathrm{x}$ if $\mathrm{x}$ helps in the prediction of $\mathrm{y}$, or equivalently if the coefficients on the lagged x's are statistically significant. For more detail see (Granger, 1969).

Our interest is to check four alternative causal relations between house prices (HPI) and stock prices (SPI). These are:

- $\quad$ Unidirectional causality runs from stock prices (SPI) to house prices (HPI), in other words, stock prices (SPI) Granger causes house prices (HPI). This will support wealth effect theory.

- $\quad$ Unidirectional causality runs from house price (HPI) to stock prices (SPI), in other words, house prices (HPI) Granger causes stock prices (SPI). This will support the credit-price effect theory.

- $\quad$ Feedback system, the possibility that stock prices (SPI) Granger causes house prices (HPI) and house prices Granger causes stock prices (SPI), in this case both effects will be supported.

- $\quad$ No Granger causality exists in the system, where both house prices (HPI) and stock prices (SPI) are independent.

Impulse response functions show the responses of endogenous variables as a result to the change in one innovation in the system. In other word, an impulse response function traces the effect of one standard deviation shock to one of the innovations on current and future values of the endogenous variables. Variance decomposition provides information about the relative importance of the random innovations. It shows the sources of errors in forecasting the endogenous variables.

\section{Empirical Results}

Running the Unrestricted Vector Atuoregression model (UVAR) using nonstationary variables will produce hazardous results (Sims, Stock, \& Watson, 1990). Therefore, the first step to be done is to check stationarity of all variables included in the system in their level form.

\subsection{Stationarity Test}

The Augmented Dickey-Fuller (ADF) test (Note 1) was conducted using the following equations:

$$
\begin{gathered}
\Delta Y_{t}=a_{0}+\beta Y_{t-1}+\sum_{i=1}^{k} \gamma \Delta Y_{t-i}+u_{t} \\
\Delta Y_{t}=a_{0}+a_{1} t+\beta Y_{t-1}+\sum_{i=1}^{k} \gamma \Delta Y_{t-i}+u_{t}
\end{gathered}
$$

where, $\Delta \mathrm{Y}_{\mathrm{t}}$ is the first difference of the series $\mathrm{Y}, \mathrm{k}$ is the number of lags, and $t$ stands for the time period. Equation (5) with constant, and no time trend, and equation (6) is with constant and with-time trend. The null and alternative hypotheses may be written as:

$\mathrm{H} 0: \beta=0$;

$\mathrm{H} 1: \beta<0$.

and evaluated using the conventional $\mathrm{t}$-ratio for $\beta$ :

$$
t \beta=\beta^{\wedge} /\left(\operatorname{se}\left(\beta^{\wedge}\right)\right)
$$

Where $\beta^{\wedge}$ the estimate of $\beta$, and se $\left(\beta^{\wedge}\right)$ is the coefficient standard error. The lag length $(\mathrm{k})$ was determined based on Akaike's information criterion (AIC).

Table 2 represents the result of unit root test using the Augmented Dickey-Fuller (ADF) for all the variables. Results show that all variables are not stationary in their levels at the $5 \%$ level of significance, but they are in 
first difference.

Table 2. Augmented Dickey-Fuller (AD-F) unit root rest results

\begin{tabular}{lll}
\hline Test Variable & AD-F Intercept & Intercept, trend \\
\hline LHPI & $0.23(2)$ & $-1.45(1)$ \\
$\Delta$ LHPI & $-3.09(1) * *$ & $-3.29(1) *$ \\
LRGDP & $1.55(0)$ & $-0.59(0)$ \\
$\Delta$ LRGDP & $-4.51(0) * * *$ & $-5.06(0) * * *$ \\
LSPI & $-1.24(0)$ & $-2.76(2)$ \\
$\Delta$ LSPI & $-6.19(0) * * *$ & $-6.11(0) * * *$ \\
\hline
\end{tabular}

Note. ${ }^{* *}, * *, *$, denotes that the null hypotheses that a variable contains a unit root is rejected at $1 \%, 5 \%$ and $10 \%$ significance level, respectively. The value with ( ) indicates the optimal number of lags. $\Delta$ First difference.

\subsection{Cointegration Tests}

Since the results of stationarity tests show that all variables are nonstationary in their level form, but they are in first difference and then they are integrated of the same order, i.e., I (1). Thus, the variables in the system should be tested for cointegration. In a situation of cointegration presence, it is necessary to estimate the unrestricted VAR model using an error correction model form using equations 3 , and 4.

The Johansen's cointegration tests (Note 2) were performed by allowing an intercept in both the cointegrating equation and test VAR. The cointegration tests used two lags length, which is based on Akike's Information Criterion (AIC). Results of cointegration tests are presented in Table 3. As can be seen in Table 3 results from both tests (trace and max-eigenvalue rank) indicate that no cointegration exists among the variables included in the system at both 5 percent and 1 percent level of significance. This means that there is no long-run relationship exists between the variables included in the system.

Table 3. Results of johansen cointegration tests with optimal lag length of two

\begin{tabular}{llll}
\hline $\begin{array}{l}\text { Hypothesized } \\
\text { No. of CE(s) }\end{array}$ & Trace Statistic & $5 \%$ Critical Value & 1\% Critical Value \\
\hline $\mathrm{R}=0$ & $28.38^{*}$ & 29.79 & 35.45 \\
$\mathrm{R} \leq 1$ & $9.59^{*}$ & 15.49 & 19.93 \\
$\mathrm{R} \leq 2$ & $1.29 *$ & 3.84 & 6.63 \\
\hline Hypothesized & & & \\
No. of CE(s & Max-Eigen Statistic & $5 \%$ Critical Value & $1 \%$ Critical Value \\
\hline $\mathrm{R}=0$ & $18.79^{*}$ & 21.13 & 25.86 \\
$\mathrm{R} \leq 1$ & $8.29^{*}$ & 14.26 & 18.52 \\
$\mathrm{R} \leq 2$ & $1.29 *$ & 3.84 & 6.63 \\
\hline
\end{tabular}

Note. *Both Trace and Max-eigenvalue tests indicate no cointegration at both $5 \%$ and $1 \%$ levels of significance.

\subsection{Estimation Unrestricted VAR}

This section reports results of the study variables' dynamic interactions via Granger causality tests, Impulse Response Functions (IRF) and Variance Decomposition.

Known that all the variables included in this study are nonstationary and not cointegrated in their level form, standard unrestricted VAR model has been applied to analyze the relationship between stock price index and house price index. Transforming the variables to stationary series by taking first difference is recommended by econometric literature. The descriptive statistics for the variables in their first difference form are provided in table 4. Stationarity result for all variables in their first difference form is provided in Table 2. The results show that all variables in first difference are stationary. Thus, all variables were entered into the UVAR model based on their first difference form. The estimated UVAR used two lags; the choice of two lags is supported by Akaike's Information Criteria (AIC). VAR result is shown using the resulted VAR causality, impulse response functions and variance decomposition. Diagnostic tests results for the estimated model were reported as follows: the stability test result is shown in Table A1, serial correlation test result is shown in Table A2, residual normality 
test result is shown in Table A3 and Heteroskedasticity tests is shown in Table A4. All results suggest that UVAR (2) satisfies the stability condition, free of serial correlation, satisfies the normality condition and free of Heteroskedasticity respectively.

Table 4. Summary statistics of the sample series used in the VAR model

\begin{tabular}{lccc}
\hline Variable Descriptive & $\Delta$ LHPI & $\Delta$ LRGDP & $\Delta$ LSPI \\
\hline Mean & 0.013616 & 0.040417 & 0.084700 \\
Median & 0.001001 & 0.047321 & 0.078359 \\
Maximum & 0.161182 & 0.087129 & 0.711272 \\
Minimum & -0.150070 & -0.038326 & -0.832165 \\
Std. Dev. & 0.067180 & 0.035364 & 0.358612 \\
Skewness & -0.251845 & -0.334325 & -0.695165 \\
Kurtosis & 3.834298 & 2.019681 & 3.876624 \\
Jarque-Bera & 1.068475 & 1.584132 & 3.039175 \\
Probability & 0.586116 & 0.452908 & 0.218802 \\
\hline
\end{tabular}

Note. The $\Delta$ denotes to the changes in the variables.

\subsection{VAR Causality Test}

Based on Granger (1988), the direction of causality between house prices (HPI) and stock prices (SPI) is determined by means of standard F test, or Wald type Granger Causality test produced from an unrestricted vector autoregressive (UVAR) (Note 3).

Table 5 shows the results of Granger non-causality test. Results of short-run Granger causality can be summarized as follows: 1 ) there is a statistically significant direct causal relationship that runs from the real GDP (RGDP) to the house price index (HPI). 2) there is a statistically significant direct causal relationship that runs from the stock price index (SPI) to house price index (HPI).3) there is no statistically significant direct causal relationship that runs from house price index (HPI) or from stock price index (SPI) to real GDP (RGDP). 4) There is no statistically significant direct causal relationship that runs from house price index (HPI) or from real GDP (RGDP) to stock price index (SPI).

Table 5. Granger causality/block exogeneity wald test with optimal lag length of two

\begin{tabular}{llll}
\hline Dependent variable: $\Delta$ LHPI & & \\
\hline Excluded & Chi-sq & df & Probability-Value \\
$\Delta$ LRGDP & $11.86729 *$ & 2 & 0.0026 \\
$\Delta$ LSPI & $14.09077^{*}$ & 2 & 0.0009 \\
All & 17.52960 & 4 & 0.0015 \\
\hline Dependent variable: $\Delta$ LRGDP & & \\
\hline Excluded & Chi-sq & df & Probability-Value \\
$\Delta$ LHPI & 0.147622 & 2 & 0.9288 \\
$\Delta$ LSPI & 3.506112 & 2 & 0.1732 \\
All & 3.563086 & 4 & 0.4684 \\
\hline Dependent variable: $\Delta$ LSPI & & \\
\hline Excluded & Chi-sq & df & Probability-Value \\
$\Delta$ LHPI & 0.612306 & 2 & 0.7363 \\
$\Delta$ LRGDP & 2.670994 & 2 & 0.2630 \\
All & 3.073890 & 4 & 0.5455 \\
\hline
\end{tabular}

Note. $*$ indicates the rejection of null hypothesis at $1 \%$ level of significance.

\subsection{Impulse Response Functions (IRF's)}

The IRF's trace out the responses of the dependent variables in the VAR system which is result from the change in one of the innovations \&t. In other words, an impulse response function traces the effect of one standard deviation shock on one of the innovations on current and future values of the endogenous variables. Generalized 
Impulses which is described by Koop, Pesaran and Potter (1996) and Pesaran and Shin (1998) to construct an orthogonal set of innovations that does not depend on the VAR ordering were applied.

(a)

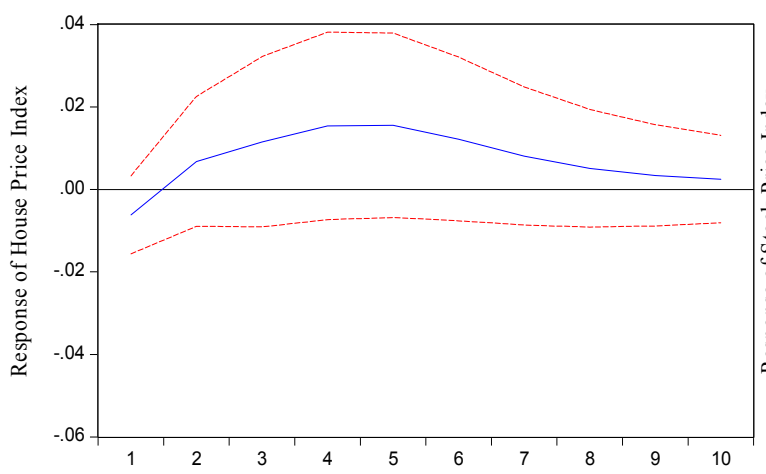

Time (Years) (b)

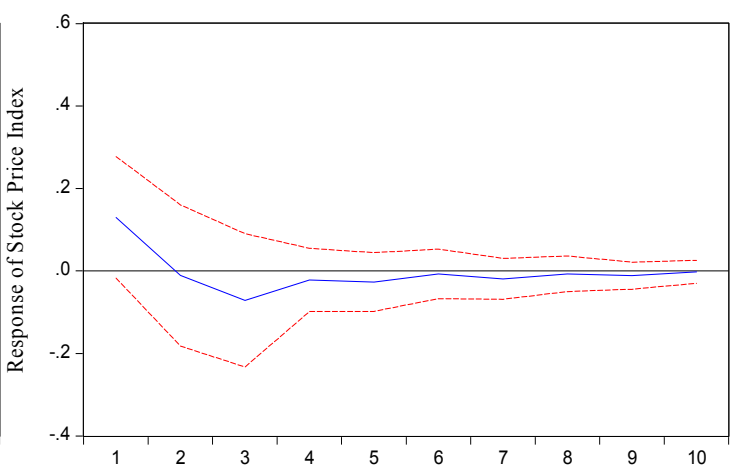

Time (Years)

Figure 2. Impulse response functions to a shock to real GDP

Note. Response to Generalized One S.D. Innovations \pm 2 S.E.

(c)

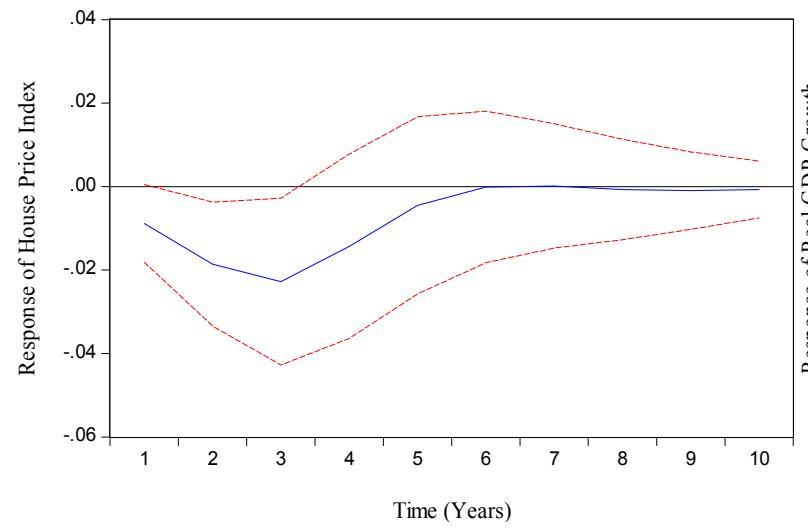

(d)

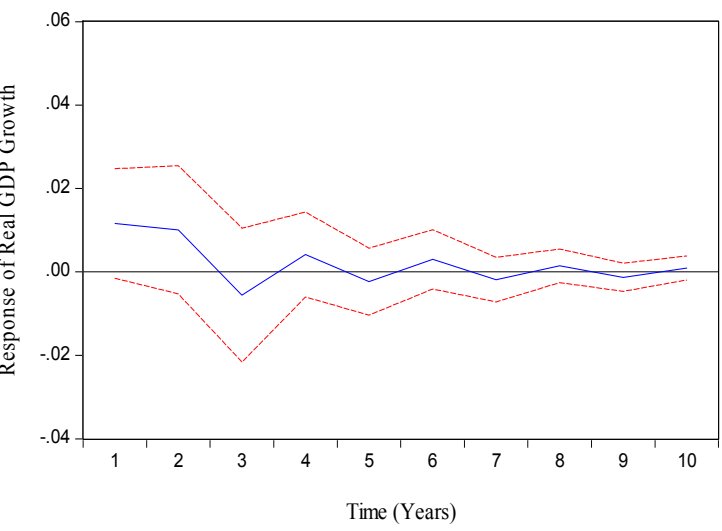

Figure 3. Impulse response functions to a shock to stock price index

Note. Response to Generalized One S.D. Innovations \pm 2 S.E.

(e)

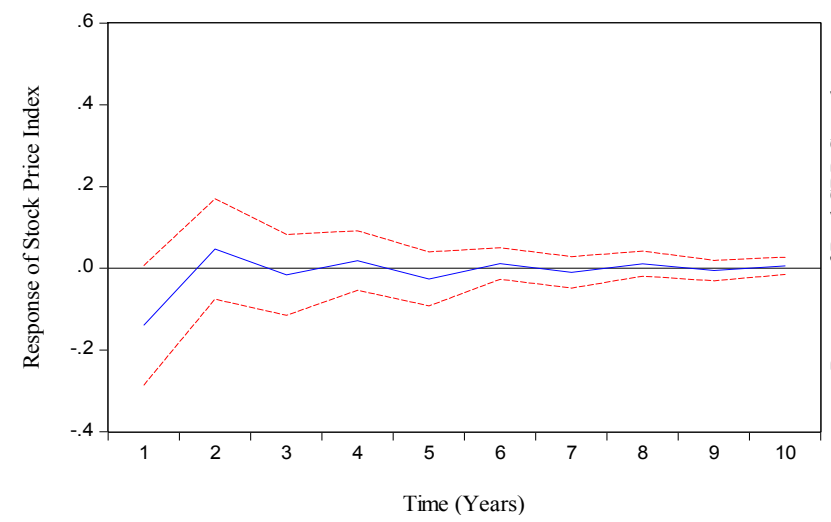

(f)

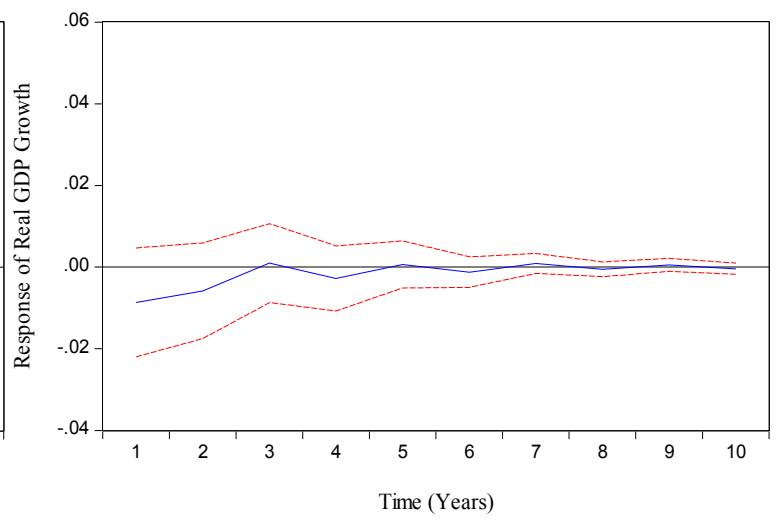

Figure 4. Impulse response functions to a shock to house price index

Note. Response to Generalized One S.D. Innovations \pm 2 S.E. 
Impulse response functions are reported in figures 2, 3, and 4. Figure 2 presents responses of house price index and stock price index to a positive one standard deviation innovation in real GDP growth. Figure 2a shows there is a positive (statistically significant) response of house price index to a positive shock in real GDP growth. This means that an increase in economic growth leads to an increase in house prices (positive relationship). This finding is consistent with Ibrahim, Padli, and Baharom (2009).

Figure $2 \mathrm{~b}$ shows there is a positive response in stock price index as result of a positive shock in real GDP growth for the first year and after that the effect becomes negative. However the responses remain statistically insignificant in all cases.

Figure 3 shows responses of house price index and real GDP growth to a positive one standard deviation innovation in stock price index. Figure $3 \mathrm{c}$ shows that there is a negative (statistically significant) response of house price index to a positive shock in stock price index, which means an increase in the stock price index leads to a decrease in the houses price index (negative relationship). This result is consistent with Ibbotson and Siegel (1984); Hartzell (1986); Worzala and Vandell (1993); Gyourko and Keim (1992); Eichholtz and Hartzell (1996). Figure $3 \mathrm{~d}$ shows that there is positive (statistically insignificant) response in real GDP growth to the change in stock price index for almost two years and then becomes negative for one year before vanishing.

Figures $4 \mathrm{e}$ and $4 \mathrm{f}$ show that there are negative (statistically insignificant) responses in stock price index and real GDP growth respectively to a positive shock in house price index, this effect vanish after two years.

\subsection{Variance Decomposition}

The variance decomposition provides information about the relative importance of each random innovation affects the dependent variables in the VAR.

Table 6 shows the most important variable that explains house price index which is the stock price index. At four years horizon, the stock price index explains 41.45 percent of the variation in the house price index. Real GDP explains about 21.15 percent of the variation in house price index at 4 years horizon, and then increased to 30.38 percent at 8 years horizon.

Table 7 shows that the most important variable explains the real GDP which is itself all years. The house price index and stock price index appear to have a very small effect on real GDP, house price index explains at most 8.57 percent at 10 years horizon, and stock price index explains at most 9.52 at 10 years horizon.

Table 8 shows that the most important variable explains the stock price index which is itself all of the time, the second most important variable is house price index, and third is real GDP. But the effect of house price index and stock price index appear very weak.

Table 6. Variance decompositions of house price index ( $\Delta$ LHPI)

\begin{tabular}{llll}
\hline Period & $\Delta$ LHPI & $\Delta$ LRGDP & $\Delta$ LSPI \\
\hline 1 & 100.00 & 0.00 & 0.00 \\
2 & 71.43 & 11.08 & 17.48 \\
4 & 37.38 & 21.15 & 41.45 \\
6 & 32.25 & 28.69 & 39.04 \\
8 & 31.35 & 30.38 & 38.25 \\
10 & 31.14 & 30.67 & 38.17 \\
\hline
\end{tabular}

Table 7. Variance decomposition of real GDP growth ( $\Delta$ LRGDP)

\begin{tabular}{lccc}
\hline Period & $\Delta$ LHPI & $\Delta$ LRGDP & $\Delta$ LSPI \\
\hline 1 & 6.56 & 93.43 & 0.00 \\
2 & 8.49 & 88.07 & 3.43 \\
4 & 8.53 & 83.61 & 7.85 \\
6 & 8.52 & 82.50 & 8.97 \\
8 & 8.56 & 82.09 & 9.34 \\
10 & 8.57 & 81.90 & 9.52 \\
\hline
\end{tabular}


Table 8. Variance decomposition of stock price index ( $\Delta$ LSPI)

\begin{tabular}{lccc}
\hline Period & $\Delta$ LHPI & $\Delta$ LRGDP & $\Delta$ LSPI \\
\hline 1 & 13.51 & 6.63 & 79.84 \\
2 & 14.71 & 6.48 & 78.80 \\
4 & 13.78 & 9.86 & 76.34 \\
6 & 13.76 & 10.24 & 75.98 \\
8 & 13.68 & 10.40 & 75.90 \\
10 & 13.66 & 10.46 & 75.87 \\
\hline
\end{tabular}

\section{Conclusion}

This paper has examined the dynamic relationship between house prices and stock prices using unrestricted VAR model in Saudi Arabia. GDP has been included in the model. Conclusions were based on Granger causality test, impulse response functions and variance decompositions that were simulated from the estimated unrestricted vector autoregressive (VAR).

The results which were obtained from the analyses can be summarized as follows: First, no long-run relationship exists among the three variables model in this study. Second, stock prices play a major role in determining the changes in house prices. Third, the relationship between the house prices and stock prices is negative. Forth, the economic growth fluctuations play a major role in determining the changes in house prices and the relationship is positive. Fifth: there was no statistical significant effect of house prices on stock prices or real GDP.

\section{References}

Bonnie, B. J. (1998). The dynamic impact of macroeconomic aggregates on housing prices and stock of houses: A national and regional analysis. Journal of Real Estate Finance and Economics, 17(2), 179-197. http://dx.doi.org/10.1023/A:1007753421236

Dickey, D. A., \& Fuller, W. A. (1981). Likelihood ratio statistics for autoregressive time series with a unit root. Econometrica, 49, 1057-1072. http://dx.doi.org/10.2307/1912517

Dickey, D., \& Fuller, W. (1979). Distribution of the estimators for autoregressive time series with a unit root. Journal of the American Statistical Association, 44 , 427-431. http://dx.doi.org/10.1080/01621459.1979.10482531

Eichboltz, P. M. A., \& Hartzell, D. J. (1996). Property shares, appraisals and the stock market: an international perspective. Journal of Real Estate Finance and Economics, 12(2), 163-178. http://dx.doi.org/10.1007/BF00132265

Granger, C. (1969). Investigating causal relations by econometric models and cross-spectral methods. Econometrica, 37, 424-438. http://dx.doi.org/10.2307/1912791

Granger, C. (1988). Some recent developments in a concept of causality. Journal of Econometrics, 39, $199-211$. http://dx.doi.org/10.1016/0304-4076(88)90045-0

Gyourko, J., \& Keim, D. B. (1992). What does the stock market tell us about real estate returns? Real Estate Economics, 20(3), 457-485. http://dx.doi.org/10.1111/1540-6229.00591

Hartzell, D. (1986). Real estate in the portfolio. In E. J. Fabozzi (Ed.), The Institutional Investor: Focus on Investment Management. Cambridge, Massachusetts: Balliger.

Hui, E. C. M., \& Ng, I. M. H. (2012). Wealth effect, credit price effect, and the inter-relationships between Hong Kong's property market and stock market. Property Management, 30(3), 255-273. http://dx.doi.org/10.1108/02637471211233864

Ibbotson, R., \& Siegel, L. (1984). Real estate returns: a comparison with other investment. AREUEA Journal, 12, 219-241. http://dx.doi.org/10.1111/1540-6229.00320

Ibrahim, H. (2010). House price-stock price relations in Thailand: An empirical analysis. International Journal of Housing Markets and Analysis, 3, 69-82. http://dx.doi.org/10.1108/17538271011027096

Ibrahim, M. H, Padli, J., \& Baharom, A. H. (2009). Long-run relationships and dynamic interactions between housing and stock prices in Thailand. Asian Academy of Management Journal of Accounting and Finance, 5(1), 93-105. Retrieved from http://scholar.google.com/scholar?q=Longrun+relationships+and+dynamic+interactions+between+housing 
+ and + stock + prices + in ++ Thailand $\&$ hl $=$ en\&as_sdt=0\&as_vis $=1 \& o i=$ scholart\&sa $=X \&$ ei $=2 \mathrm{KtrVIOkNYzIsQ}$ TRxYDQDA\&ved=0CBsQgQMwAA

Johansen, S. (1988). Statistical analysis of co-integration vectors. Journal of Economic Dynamics and Control, 12, 231-254. http://dx.doi.org/10.1016/0165-1889(88)90041-3

Johansen, S., \& Juselius, K. (1990). Maximum likelihood estimation and inference on cointegration: With applications to the demand for money. Oxford Bulletin of Economics and Statistics, 52(2), 169-210. http://dx.doi.org/10.1111/j.1468-0084.1990.mp52002003.x

Kakes, J., \& Van den End, J. W. (2004). Do stock prices affect house prices? Evidence for the Netherlands. Applied Economics Letters, 11, 741-744. http://dx.doi.org/10.1080/1350485042000254863

Kapopoulos, P., \& Siokis, F. (2005). Stock and real estate prices in Greece: Wealth versus 'credit-price' effect. Applied Economics Letters, 12, 125-128. http://dx.doi.org/10.1080/1350485042000307107

Koop, G., Pesaran, M., \& Potter, S. (1996). Impulse response analysis in nonlinear multivariate models. Journal of Econometrics, 94. http://dx.doi.org/10.1016/0304-4076(95)01753-4

Lizieri, C., \& Satchell, S. (1997). Interactions between property and Equity Markets: An Investigation of Linkages in the United Kingdom 1972-1992. Journal of Real Estate Finance and Economics, 15(1), 11-26. http://dx.doi.org/10.1023/A:1007745204491

MacKinnon, J. G. (1996). Numerical distribution functions for unit root and co-integration tests. Journal of Applied Econometrics,

11 ,

601-618. http://dx.doi.org/10.1002/(SICI)1099-1255(199611)11:6<601::AID-JAE417>3.0.CO;2-T

Oikarinen. (2010). Foreign ownership of stocks and long-run interdependence between national housing and stock markets - evidence from Finnish data. Journal of Real Estate Finance and Economics, 41, 486-509. http://dx.doi.org/10.1007/s11146-009-9175-1

Pesaran, M. H., \& Shin, Y. (1998). Generalized impulse response analysis in linear multivariate models. Economics Letters, 58, 17-29. http://dx.doi.org/10.1016/S0165-1765(97)00214-0

Quan, D. C., \& Titman, S. (1999). Do real estate prices and stock prices move together? An international analysis. Real Estate Economics, 27(2), 183-207. http://dx.doi.org/10.1111/1540-6229.00771

Sim, S. H., \& Chang, B. K. (2006). Stock and real estate markets in Korea: Wealth or credit-price effect. Journal of Economic Research, 11, 99-122. Retrieved from http://jer.hanyang.ac.kr/issue/11_1/11-1-05.pdf

Sims, C., Stock, J., \& Watson, M. (1990). Inference in linear time series models with some unit root. Econometrica, 58(1), 113-144. http://dx.doi.org/10.2307/2938337

Sing, T. F., \& Tan, Z. Y. (2013). Time-varying correlations between stock and direct real estate returns. Journal of Property Investment \& Finance, 31(2), 179-195. http://dx.doi.org/10.1108/14635781311302591

Takala, K., \& Pere, P. 1991). Testing the cointegration of house and stock prices in Finland. Finnish Economic Papers, 4, 33-51. Retrieved from http://taloustieteellinenyhdistys.fi/images/stories/fep/f1991_1d.pdf

Worzala, E., \& Vandell, K. (1993). International direct real estate investments as alternative portfolio assets for institutional investors: an evaluation. Paper presented at the 1993 AREUEA Meetings, Anaheim, CA.

\section{Notes}

Note 1. for more information, see Dickey and Fuller (1979, 1981).

Note 2. cointegration tests using the methodology developed in Johansen $(1988,1995)$ performed. Consider a VAR of order $\mathrm{p}$ presented by:

$$
y_{t=} a_{0}+a_{1} y_{t-1}+a_{2} y_{t-2}+\ldots+a_{p} y_{t-p}+\varepsilon_{t}
$$

where, $y_{t}$ is $n \times 1$ vector of non-sattionary I(1) variables, $a_{i}$ is $n \times n$ matrix of parameters, and $\varepsilon_{t}$ is $n \times 1$ column vector of error terms. This VAR can be written as:

where:

$$
\Delta y_{t}=a_{0}+\Pi y_{t-1}+\sum_{i=1}^{p-1} \Gamma_{i} \Delta y_{t-1}+\varepsilon_{t}
$$




$$
\Pi=\sum_{i=1}^{p} a_{i}-I \text { and } \Gamma=-\sum_{j=i+1}^{p} a_{j} .
$$

If the coefficient matrix $\Pi$ has reduced rank $r<n$, then there exist $n \times r$ matrices $\alpha$ and $\beta$ each with rank $r$ such that $\Pi=\alpha \beta$ and $\beta y_{t}$ is stationary. $r$ is the number of cointegrating relationships, the elements of $\alpha$ are known as the adjustment parameters in the vector error correction model and each column of $\beta$ is a cointegrating vector. Johansen introduces two different likelihood ratio test of the significance of these canonical correlations and thereby the reduced rank of the $\Pi$ matrix: the trace test and maximum eigenvalue test, shown in equations (7) and (8) respectively.

$$
L R_{\text {trace }}=-T \sum_{i=r+1}^{n} \ln \left(1-\lambda_{i}\right)
$$

where, $T$ is the sample size and $\lambda_{\mathrm{i}}$ is the $i^{\text {th }}$ largest eigenvalue of the $\Pi$ matrix. The null hypothesis in trace statistics of $r$ cointegrating vectors against the alternative hypothesis of $n$ cointegrating vectors, where $n$ is the number of endogenous variables. The maximum eigenvalue test is:

$$
L R_{\max }=-T \ln \left(1-\lambda_{r+1}\right)
$$

The maximum eigenvalue test, tests the null hypothesis of $r$ cointegrating vectors against the alternative hypothesis of $r+1$ cointegrating vectors.

Note 3. The unrestricted VAR represents houses price (HPI) and stocks price (SPI) as a linear functions.

$$
\begin{aligned}
& H P I_{t=} \alpha_{0}+\mu_{1} H P I_{t-1}+\ldots \mu_{P} H P I_{t-P}+\beta_{1} R G D P_{t-1}+\ldots+\beta_{p} R G D P_{t-p}+\delta_{1} S P I_{t-1}+\ldots+\delta_{p} S P I_{t-p}+u_{1 t} \\
& S P I_{t=} \gamma_{0}+\varphi_{1} S P I_{t-1}+\ldots \varphi_{P} S P I_{t-P}+\rho_{1} R G D P_{t-1}+\ldots+\rho_{p} R G D P_{t-p}+\sigma_{1} H P I_{t-1}+\ldots+\sigma_{p} H P I_{t-p}+u_{2 t}
\end{aligned}
$$

In this context, SPI is said to Granger cause HPI if past values of SPI contribute in explaining current HPI that is the coefficients of lags SPI in HPI equation are jointly significant in terms of a standard F and/or Wald type tests. For example, in the first equation the null hypothesis that SPI does not Granger-cause HPI, i.e., $\delta_{1}=\delta_{2}=\delta_{\mathrm{P}}=0$, is rejected if the $\delta$ 's are significant as a group. While, in the second equation, the null hypothesis that HPI does not Granger-cause SPI, i.e., $\sigma_{1}=\sigma_{2}=\delta_{\mathrm{p}}=0$, is rejected if the $\sigma$ 's are significant as a group.

\section{Appendix A}

Table A1. Root and modulus of characteristic polynomial endogenous variables

\begin{tabular}{ll}
\hline Root & Modulus * \\
\hline-0.789459 & 0.78 \\
0.701881 & 0.70 \\
$0.280978-0.475009 \mathrm{i}$ & 0.55 \\
$0.280978+0.475009 \mathrm{i}$ & 0.55 \\
0.279356 & 0.27 \\
0.111799 & 0.11 \\
\hline
\end{tabular}

Note. *The VAR (2) satisfies the stability condition.

Table A2. VAR residual serial correlation LM tests

\begin{tabular}{lll}
\hline Lags & LM-Stat & Probability Value * \\
\hline 1 & 11.37 & 0.25 \\
2 & 6.50 & 0.68 \\
3 & 11.56 & 0.23 \\
4 & 10.08 & 0.34 \\
5 & 4.61 & 0.86 \\
6 & 2.38 & 0.98 \\
7 & 4.40 & 0.88 \\
8 & 3.85 & 0.92 \\
\hline
\end{tabular}

Note. *All probability values support the null hypothesis of no serial correlation. 
Table A3. VAR residual normality test

\begin{tabular}{lllll}
\hline Component & Skewness & Chi-sq & df & Probability-value \\
\hline 1 & -0.037755 & 0.005939 & 1 & 0.9386 \\
2 & 0.191595 & 0.152953 & 1 & 0.6957 \\
3 & -0.182613 & 0.138949 & 1 & 0.7093 \\
Joint & & 0.297841 & 3 & 0.9604 \\
\hline Component & Kurtosis & Chi-sq & df & Probability-value \\
\hline 1 & 2.783843 & 0.048671 & 1 & 0.8254 \\
2 & 2.059199 & 0.921986 & 1 & 0.3370 \\
3 & 3.799760 & 0.666267 & 1 & 0.4144 \\
Joint & & 1.636923 & 3 & 0.6510 \\
\hline Component & Jarque-Bera & df & & Probability-value \\
\hline 1 & 0.054610 & 2 & & 0.9731 \\
2 & 1.074939 & 2 & & 0.5842 \\
3 & 0.805215 & 2 & & 0.6686 \\
Joint & 1.934765 & 6 & &
\end{tabular}

Table A4. VAR residual heteroskedasticity tests

\begin{tabular}{|c|c|c|c|c|c|}
\hline \multicolumn{6}{|l|}{ Joint Test: } \\
\hline Chi-sq & df & Prob. & & & \\
\hline 68.35394 & 72 & 0.6000 & & & \\
\hline \multicolumn{6}{|c|}{ Individual components: } \\
\hline Dependent & R-squared & $\mathrm{F}(12,12)$ & Prob. & Chi-sq(12) & Prob. \\
\hline res $1 *$ res 1 & 0.296110 & 0.420677 & 0.9261 & 7.402760 & 0.8299 \\
\hline res $2 *$ res 2 & 0.534241 & 1.147034 & 0.4080 & 13.35603 & 0.3437 \\
\hline res $3 *$ res 3 & 0.713974 & 2.496180 & 0.0634 & 17.84934 & 0.1203 \\
\hline $\operatorname{res} 2 * \operatorname{res} 1$ & 0.391540 & 0.643492 & 0.7718 & 9.788490 & 0.6345 \\
\hline res3*res 1 & 0.243569 & 0.321997 & 0.9696 & 6.089218 & 0.9115 \\
\hline res $3 *$ res 2 & 0.516117 & 1.066614 & 0.4564 & 12.90292 & 0.3761 \\
\hline
\end{tabular}

\section{Copyrights}

Copyright for this article is retained by the author(s), with first publication rights granted to the journal.

This is an open-access article distributed under the terms and conditions of the Creative Commons Attribution license (http://creativecommons.org/licenses/by/3.0/). 